\title{
Omphalosphere: New York 2057
}

\author{
A trip to the Zoo, a visit to the Library.
}

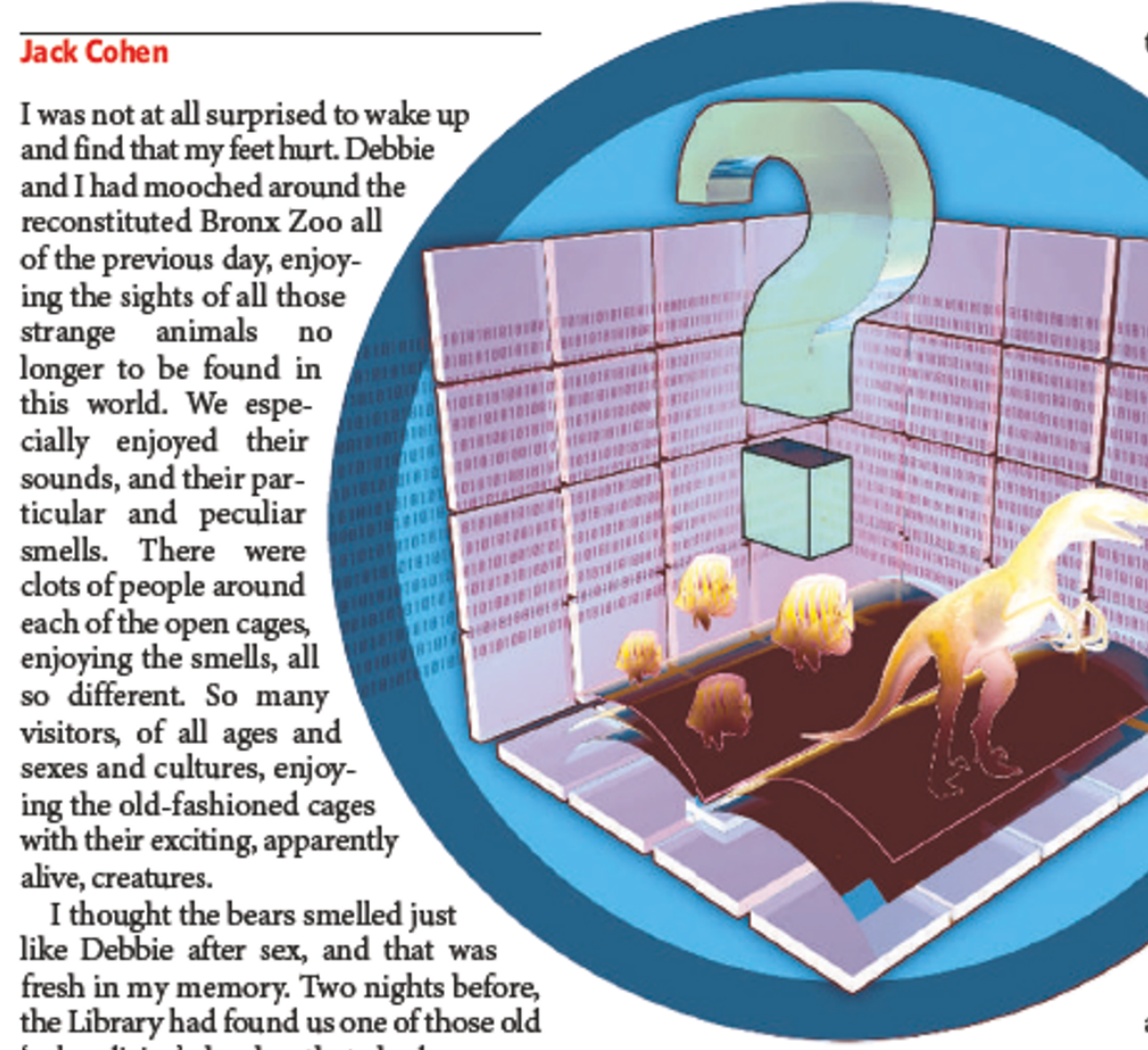
'aphrodisiac' books that had recommended the addition of a little pepper or if you were braver, chillies - to lovemaking, and we were both regretting this as we walked around the park, despite the considerable volumes of unguents we'd applied to each other. We laughed at the ostriches, and found the elephants nearly as unbelievable as the tyrannosaurs. The aquarium exhibits were simply beautiful, along many axes, from the simply colourful to the ornately grotesque, from the lean lithe predators to the amazingly camouflaged prey, from the coral organisms with their symbiotic algae to their larvae in the busy world of the plankton. Determined to learn some more biology this afternoon.

What was on the agenda today? Ah, Moshe and his research on ancient religions, souls and eternities. A mutual friend, Ali, who taught theology at Columbia University, had found an old, 1930 s parable by an early scientist called Haldane, explaining to his audience what eternity was by imagining a Neapolitan street-sweeper child wafted to 'Heaven', and his God offering to have a bird drop a feather on a mountain once a century: "When the mountain is worn away..."

"No," Haldane's child had said (anticipating Pascal's many infinities). "Long before the feathers have had any effect, the world of birds, feathers and mountains will have been superseded." And so on. "Our successors will think of our time as a pre-Creation eternity: our predecessors found eternity as our time unfolded. A very pretty little parable.

Where, Moshe and Ali wondered, was this 'Heaven', where 'souls' lived, where 'God" was to be found? I observed, as they discussed Plato's ideal plane of existence; and Rucker's Mindscape; and the JudaeoChristian Creation myth with its Garden of Eden so dearly lifted from the Sumerians; and the question of whether the ancients believed that Adam had a navel, the trees in the Garden had tree-rings, and the rock below had fossils - all the Created were consistent with a long causal but fictional history. The Library found Gosse's Omphalos for them, which had propounded that idea to the Victorians as the way of integrating Darwin with Creationist Christianity: God had created an 'old' Universe, and you couldn't catch the Old Guy out.

We all enjoyed coffee and liqueurs as we argued about different planes of existence, what causality was, if there were Laws of Nature that made things go the way they did. "The scientists of the twentieth century believed there were," said Ali, "and they didn't see how close to their religious friends that made them." Then Debbie appeared, and Ali's current lover, and we all found ourselves around a lunch table talking about the food and its provenance.

I thought how much they - and I - were perpetual students, rehashing all the old arguments and examples with the occasional new parable thrown in by the Library from the literature of the past. I wandered offalone towards the Bronx Zoo again.

I turned on a light rain to match my mood and wondered, again, whether any of the other thousands of virtual New Yorks had me doing exactly the same things (deciding not to experiment with chillies would have been a good idea), and whether their Libraries fed them the same material from the infinite literary and scientific resources before the Uplift.

Then it occurred to me that the Library's literary past might never actually have existed, as unreal as the pre-Creation seasons documented by the tree-rings in the Eden trees. The Library, like the God in Omphalos, might have constructed that past so that our civilization seemed rational, with a causal history. The problem for me was that I simply could not imagine a time and place, a three-or-four-dimensional causal universe like the twentieth century so vividly portrayed for us by the Library, where human beings had possessed material 'bodies' that somehow interacted directly with the world around them to implement their wishes. Their supposed belief in 'souls' seemed positively reasonable compared with the idea that human minds had once been tethered to material bodies that needed to eat, to excrete, to heal after material injury. That there had been what they called a 'reality' that people didn't even have the illusion that they controlled. That people didn't always live, as we know that we do, such rich, fulfilled lives in the machinery of the Library.

Jack Cohen is an author and reproductive biologist based in Newent,

Gloucestershire, UK. 